\title{
25 Research Soure \\ The Anomalous Weather Parameters that Lead to the Extreme Rainfall of Kerala in August 2018
}

Suneela Sreedharan ( $\nabla$ karickalr@hotmail.com )

Kerala University of Fisheries and Ocean Studies https://orcid.org/0000-0003-2565-1056

\section{Basil Mathew}

Kerala University of Fisheries and Ocean Studies

\section{Sureshkumar Sivanpillai}

Kerala University of Fisheries and Ocean Studies

\section{Research Article}

Keywords: precipitation, extreme weather, flood, Low Level Jet, global warming, anomalies, Madden Julian Oscillation, monsoon

Posted Date: July 26th, 2021

DOI: https://doi.org/10.21203/rs.3.rs-735159/v1

License: (c) (1) This work is licensed under a Creative Commons Attribution 4.0 International License. Read Full License 


\section{Abstract}

Extremely heavy rainfall has been occurred over Kerala, southwest coast of India, during mid-August 2018. The meteorological conditions during this period are analysed, and it is found that a combination of many rain favouring conditions prevailed at that time. The positive phase of Madden Julian Oscillation coupled with a monsoon depression in the Bay of Bengal and a weak trough in the south-eastern Arabian Sea strengthened the Monsoon Low Level Jet bringing moisture-laden winds over Kerala. The rising limb of Walker and Hadley circulations was also found over Kerala, which gave favourable updraft for cloud formation. In addition, the core of the Tropical Easterly Jet was found over the Kerala and Karnataka region. The cyclonic circulation in the mid-troposphere observed around the monsoon depression extended up to the west coast of India. Simultaneous occurrences of all these could have contributed to the extreme rainfall events and severe floods over Kerala.

\section{Introduction}

The Indian state of Kerala received very heavy rainfall resulting in severe floods during August 2018. Due to the floods, over 483 people lost their lives, 140 people went missing, and millions were affected. The estimated loss due to the floods is over Rs 20000 crore ( 300 billion dollars). The flood of 2018 was the severest in Kerala in about a century, where the last being the catastrophic floods in the monsoon of 1924. Extreme rainfall events are increasing worldwide in the recent period. Even though global warming could be one of the main reasons for the extreme weather events, the flood of 1924 occurred in Kerala during the pre-industrial era. This flood might have caused by offshore vortices along the west coast and upper tropospheric perturbations as there were no depressions or cyclonic storms in the Arabian Sea or the Bay of Bengal during that period (Ramaswamy 1985). According to the National Oceanic and Atmospheric Administration (NOAA), the present-day annual average atmospheric temperature is $1.19^{\circ} \mathrm{C}$ warmer than in the pre-industrial era. As the atmosphere becomes warm, potential evaporation increases enhancing the formation of cyclonic systems and associated extreme weather conditions, especially rainfall. With a $1.0^{\circ} \mathrm{C}$ increase in temperature, the water-holding capacity of the atmosphere increases by about $6-7 \%$, leading to more intense and frequent extreme precipitation events (Kharin et al. 2007; Trenberth et al. 2003). The water holding capacity of the atmosphere increases almost exponentially with temperature, and the atmospheric water content also increases with temperature (Pall et al. 2007; Santer et al. 2007; Willett et al. 2007). Using observed extreme rainfall data and multi-model simulations, Min et al. (2011) showed that human-induced increase in greenhouse gases influence the intensification of extreme precipitation events. A rise of $1.5^{\circ} \mathrm{C}$ in global mean temperature from the preindustrial era can increase the three hourly precipitation maxima by $20 \%$ (Ali and Mishra 2018). Mishra (2019) also attributes the heavy precipitation events to global warming, specifically to increased extreme precipitation and a decrease in moderate and light precipitation. This study shows that for a $1.0^{\circ} \mathrm{C}$ increase in regional warming, about $4.98 \% \pm 1.26 \%$ increase can occur in the precipitable water vapour content. During the last few decades, the frequency and intensity of extreme precipitation events have increased in India, which can be attributed to global warming (Mukherjee et al. 2018; Myhre et al. 
2019; Pai et al. 2015). O'Gorman ( 2015) discussed different physical factors influencing the response of extreme precipitation like dynamical contribution, orographic contribution, mesoscale convection and warming and concluded that precipitation extremes intensify with the warming climate.

Extreme rainfall events and associated flooding has increased recently in many parts of India. The frequency and intensity of extreme rain events show a significant increasing trend and a decreasing trend in the frequency of moderate events over central India during the monsoon season from 1951 to 2000 (Goswami et al. 2006). In central and north India, extreme rainfall has decreased, while in peninsular India, it has increased (Guhathakurta 2011). Trend analysis of rainfall events for northeast India showed a significant decrease in low rainfall events and an increase in very high and extremely high rainfall events (Varikoden and Revadekar 2020). The extreme rainfall events in this region are due to the strengthening of the southerly component of low-level wind from the Bay of Bengal and the updraft due to convergence at $850 \mathrm{hPa}$ level. Studies using the models, Weather Research \& Forecasting (WRF) with the hydrological model (WRF-hydro), showed that the extreme rainfall events could be $18 \%$ less while considering the decreased number of monsoon low-pressure systems than in the pre-industrial era. However, extreme rainfall events can be $36 \%$ more due to the moisture availability in the tropical atmosphere as a result of warming (Hunt and Menon 2020). There exist large differences between contributions from largest ( $80.7 \%)$ and deepest (53\%) extreme rainfall events while considering the top $1 \%$ of extreme events in global precipitation (Kumar et al. 2019). Even though the frequency of the Bay of Bengal depressions has decreased, over central India, widespread extreme rainfall events have increased threefold during 1950-2015 (Roxy et al. 2017). The extreme rainfall event of Chennai during 30th November - 2nd December 2015 shows a positive correlation with the southern Bay of Bengal SST (Boyaj et al. 2018). Kumar et al. (2009) suggest that the northern Indian Ocean warmed in recent years, especially the Arabian Sea, resulting in increased cyclogenesis and extreme weather events.

The state of Kerala experienced abnormally heavy rainfall during the monsoon season of 2018, which caused flooding in almost all districts of Kerala. According to India Meteorological Department, Kerala received $2346.6 \mathrm{~mm}$ of rainfall from $1 \mathrm{st}$ June 2018 to 19th August 2018, whereas the normal rainfall is only $1649.5 \mathrm{~mm}$. The increase in rainfall was about $43 \%$ above normal, and in August, it was $164 \%$ above normal. Because of continuous rainfall from $1^{\text {st }}$ June onwards, several reservoirs in the state were at their full reservoir level. According to Mishra et al. (2018), on $8^{\text {th }}$ August 2018, most of the major reservoirs in Kerala were more than $90 \%$ of their capacity. When another severe spell of rainfall started on $14^{\text {th }}$ August with torrential precipitation almost all over Kerala, the reservoirs had to release water, resulting in flooding all over Kerala. However, analysis of the flood situation in the Periyar River Basin in August 2018 showed that only $16-21 \%$ peak attenuation was possible by emptying the reservoir in advance and that the intermediate catchments which had no reservoirs to control the flow contributed 
large runoff to the flood event (Sudheer et al. 2019). An assessment of the Kerala flood situation in August 2018 was done by Agarwal (2018) and made suggestions to tackle the problems in the future.

The extreme weather event during August 2018 in Kerala was attributed to anomalous weather conditions rather than the warming trend in the atmosphere by Mishra and Shah (2018). Modifications in the land cover resulted in higher surface temperatures, sensible heat flux, and a deeper and moist boundary layer, resulting in heavy precipitation (Boyaj et al. 2020). According to Viswanadhapalli et al. ( 2019), high convective instability, offshore vortex, moisture transport from mid-troposphere due to horizontal wind shear and mid-tropospheric moisture transport from the Bay of Bengal played major roles in the extreme precipitation event. Kumar et al. (2020) showed that the synergic interaction of a lowpressure system in the northern Bay of Bengal, an offshore trough in the south-eastern Arabian Sea and mid-tropospheric dry air intrusion from the Middle East due to an anticyclone caused the extreme rainfall events. This study, investigates the different weather parameters that influenced the peculiar weather conditions over Kerala during the 2018 monsoon season.

\section{Data}

For this study data for a period of 30 years, from 1990-2019 is used. Different meteorological parameters were downloaded from the NCEP gridded climate data set $\left(2.5^{0} \times 2.5^{0}\right)$ available from PSL (Physical Sciences Laboratory; https://psl.noaa.gov/ ). High resolution (12.5 x 12.5 km) ERA-Interim reanalysis data is taken from the site https://www.ecmwf.int. Besides this, gridded daily rainfall data $\left(0.25^{0} \times 0.25^{\circ}\right)$ from IMD was downloaded from the site

\section{https://www.imdpune.gov.in/Clim_Pred_LRF_New/Grided_Data_Download.html}

\section{Results And Discussion}

According to IMD, the average rainfall over Kerala from $1^{\text {st }}$ June to 21 st August 2018 was 2346 mm, which is $42 \%$ above normal, and from $1^{\text {st }}$ to $19^{\text {th }}$ August, it was $758.6 \mathrm{~mm}$, which is $164 \%$ above normal. There was continuous rainfall from $1^{\text {st }}$ June 2018 onwards, due to which several of the reservoirs were almost near their full reservoir level. The heavy rainfall of August 2018 caused severe floods in 13 out of the 14 districts of Kerala. On the $8^{\text {th }}$ and $9^{\text {th }}$ of August, the first severe spell of rainfall was experienced at several places, following a monsoon depression in the Bay of Bengal (Kashyap et al. 2019). The second severe spell of rainfall in August started on $14^{\text {th }}$ and lasted up to $17^{\text {th }}$ August, causing disastrous flooding as 35 of the reservoir gates had to be opened to release water while torrential rainfall was occurring almost over the entire state of Kerala. As per the Central Water Commission report, the huge quantity of runoff within the period 15-17 August 2018 was beyond the carrying capacity of most of the rivers in Kerala and resulted in overbank flows in most of the rivers and caused the severe flood situation all over Kerala (CWC 2018). 


\subsection{Weather Elements}

To study the extreme weather phenomenon of August 2018 over Kerala, different weather parameters are analysed daily at different atmospheric levels. The results are presented in Fig. 1 for a typical day, $15^{\text {th }}$ August 2018, at $850 \mathrm{hPa}$. Anomalies of the weather parameters are determined from data for 30 years from 1990 to 2019.

Fig. 1

\subsubsection{Wind}

Wind speed and direction on $15^{\text {th }}$ August 2018 , as shown in Fig.1 (1) at $850 \mathrm{hPa}$ indicate that the Low Level Jet is prominent with its core passing through southern India. The southern parts of India were experiencing strong winds of more than $16 \mathrm{~m} / \mathrm{s}$, and central to southern Kerala experienced more than 18 $\mathrm{m} / \mathrm{s}$. The strong winds at this level indicate the active phase of the monsoon (Joseph and Sijikumar 2004). The wind anomalies (Fig. 1 (2)) shown on $15^{\text {th }}$ August 2018 are calculated from daily climatologies of 1990 to 2019 . The anomalies indicate that along the southwest coast of India, the wind was 6-8 $\mathrm{m} / \mathrm{s}$ stronger than the normal values. A monsoon depression that formed on $14^{\text {th }}$ August in the head Bay of Bengal intensified on $15^{\text {th }}$ and persisted till $17^{\text {th }}$ August. The cyclonic circulation associated with the depression extended up to $400 \mathrm{hPa}$ level, and the area of coverage became wider with height. The axis of the circulation is found to tilt towards SSW with altitude. The cyclonic vorticity and convergence associated with the depression extended to the Kerala coast in the lower levels and further westward in the upper levels up to $500 \mathrm{hPa}$. The strong westerlies brought in much moisture to the whole west coast of India.

\subsubsection{Vertical velocity.}

Vertical velocity and its anomalies are plotted in Fig 1 (3) \& (4). In the lower levels up to $850 \mathrm{hPa}$, the vertical velocity is maximum along the west coast of India. The strong westerlies can bring in a lot of moisture towards the land and the above-normal low-level upward velocities, as shown in Fig. 1 (4), help in condensation and cloud formation. However, above $850 \mathrm{hPa}$ the maximum is in the head bay and the nearby eastern coastal area of India due to the presence of the monsoon depression, although positive anomalies prevail all over central and southern India up to $500 \mathrm{hPa}$. As time progresses, along with the cyclonic circulation, the vertical velocity maxima shift in the northwest direction. A gradual decrease in rainfall can be seen after $15^{\text {th }}$ August with a decrease in the intensity of vertical motion. 


\subsubsection{Zonal Gravity wave stress}

The convective activity influences the cloud top wave stress, and hence it is found to be concentrated over the inter-tropical convergence zone. Even though the zonal gravity wave drag is maximum at the lower stratosphere, this parameter shows higher values also in the lower troposphere during the monsoon months of June, July and August 2018. Fig.1 (5) shows that in August 2018, the maximum values of zonal gravity wave stress of $>0.3 \mathrm{~N} / \mathrm{m}^{2}$ at $850 \mathrm{hPa}$ level is found near the Anamudi Mountain region, the highest peak of the Western Ghats, due to the orographic effect, which is $0.15 \mathrm{~N} / \mathrm{m}^{2}$ above normal (Fig. 1 (6)). This anomalously high value can intensify the zonal wind speed, and hence the Low Level Jet became stronger. Gravity waves can enhance the spatial distribution of latent heat released by convection (Adames and Maloney 2021).

\subsubsection{Precipitable Water}

Fig. 2

Fig. 2 shows the spatial distribution of precipitable water and its anomaly on $15^{\text {th }}$ August 2018. An increase in temperature enhances the water vapour holding capacity of the atmosphere. Deep convection in the troposphere is enhanced by the water vapour content (Adames and Maloney 2021). Precipitable water vapour is maximum in the northern Bay of Bengal due to the presence of the monsoon depression. Spatial variation of anomalies shows that almost the entire Indian region experiences positive values. Most parts of Kerala exhibit positive anomalies of precipitable water greater than $6 \mathrm{~kg} / \mathrm{m}^{2}$. Under favourable conditions, this can produce torrential rainfall in the area.

\subsubsection{Madden Julian Oscillation}

Fig. 3

Madden Julian Oscillation (MJO) is one factor that affects the intraseasonal variability of the monsoon. During the active phase of MJO, precipitation intensity can increase considerably (Roxy et al. 2019; Peng et al. 2019; Anandh and Vissa 2020). Wind speed anomalies, cloudiness and precipitation analyses elucidate the presence of an active phase of MJO. Variations of Outgoing Longwave Radiation (OLR) and anomalies of wind speed are displayed in Fig. 3 (a) \& (b), respectively. In August 2018, the OLR values were consistently low for the second week, which shows the cloudy sky during these days 
associated with moisture convergence. Wind speed anomaly estimates also show consistently high values during these days. Variations in OLR and wind speed anomalies suggest the presence of an active phase of Madden Julian Oscillation during this period. This active phase can generate extreme precipitations and strengthen the Low Level Jet (LLJ).

\subsubsection{Meridional Mean of Vertical Velocity}

Fig. 4

Fig. 4 shows the vertical profile of the meridional mean of vertical velocity and its anomalies between $5 \mathrm{~N}$ \& $15 \mathrm{~N}$. The vertical velocity is maximum between the longitudes $70 \mathrm{E} \& 80 \mathrm{E}$ and between the pressure levels $800 \& 700 \mathrm{hPa}$ which is $0.015 \mathrm{~m} / \mathrm{s}$ above average. Upward motion prevails between $70 \mathrm{E} \& 80 \mathrm{E}$ from $1000 \mathrm{hPa}$ to $150 \mathrm{hPa}$ levels. This band of maximum vertical velocity shifts westward from $16^{\text {th }}$ August onward and lies between $60 \mathrm{E} \& 70 \mathrm{E}$ on $25^{\text {th }}$ August. There was a gradual decrease in rainfall over Kerala from the $16^{\text {th }}$ onwards with the shift of the band.

\subsubsection{Hadley and Walker Circulations}

Fig. 5

Fig. 5 shows the Hadley and Walker circulations on $15^{\text {th }}$ August 2018. During the period 12-16 August, the rising limb of Hadley $(10 \mathrm{~N}-20 \mathrm{~N})$ and Walker (70 E-80 E) circulations coincide over the Kerala region. This rising limb enhances the vertical motion. The vertical limb of both Hadley and Walker circulations reach above $200 \mathrm{hPa}$ level, which helps in the vertical transport of moisture from the lower troposphere to the upper troposphere. Since the relative humidity is greater than $90 \%$ over the Kerala region, the vertical motion enhances cloud formation and rainfall.

\subsubsection{Wind at $500 \mathrm{hPa}$ and $100 \mathrm{hPa}$ Levels}

Fig. 6

Interaction between low-pressure systems, offshore troughs, or secondary cyclonic vortices and intrusion of cold dry air to the mid-troposphere can help develop static instability and consequently extreme rainfalls (Nikumbh et al. 2020; Kumar et al. 2020). The present analysis shows, the intrusion of cold dry 
air is mainly from the northern side, beyond the Himalayas (Fig. 6 (a)). A weak intrusion of dry air occurs also from the Middle East. The tilt in the axis of circulation of the monsoon depression towards SSW with altitude must have brought much moisture in the mid-troposphere from the Bay of Bengal towards the SW coast of India. Fig. 6 (b) shows the upper tropospheric wind pattern at $100 \mathrm{hPa}$ level. The core of the Easterly Jet occurs over Kerala/Karnataka. The high wind shear due to this jet enhances the upward transport of moisture and cloud formation.

\subsubsection{Spatial Variations of Precipitation, Lapse Rate, Vorticity and Divergence}

Fig. 7

Spatial variation of rainfall from IMD data (Fig. 7(a)) shows a high amount of rainfall in the southwest coastal region of India on $15^{\text {th }}$ August 2018. On this day, an intense rainfall of more than $220 \mathrm{~mm}$ occurred at Idukki near the Western Ghats region. All along the southwest coast, heavy rainfall was observed on $15^{\text {th }}$ August. After $15^{\text {th }}$ August there was a gradual decrease in the amount of rainfall. In the southern peninsula, conditional instability prevails in the lower levels with maximum at $925 \mathrm{hPa}$ level (Fig. 7(b)). There the lapse rate is more than the moist adiabatic rate of $6^{\circ} \mathrm{C} / \mathrm{km}$ but less than the dry adiabatic rate of $9.8^{\circ} \mathrm{C} / \mathrm{km}$. In the presence of saturated air, this condition is conducive to the formation of rain-producing cumulonimbus clouds. Fig 7(c) shows divergence (shaded) and vorticity (contours) on $15^{\text {th }}$ August 2018 at $850 \mathrm{hPa}$. The cyclonic vorticity associated with the monsoon depression extends up to the southwest coast. In the upper levels, cyclonic vorticity is observed over a wider area. In the lower levels up to $850 \mathrm{hPa}$, two convergence maxima are observed, one in the coastal Arabian Sea and another in the Head Bay. The low-level convergence and the above-average vertical velocity and relative humidity enhance condensation and cloud formation.

\subsubsection{Potential Evaporation and Precipitable Water}

Fig. 8

The ability of the atmosphere to remove water from the surface through the evaporation process is known as potential evaporation. The major factors influencing evaporation are temperature and wind. Temperature provides the energy for evaporation, and wind removes water molecules from a surface through eddy diffusion. The more the wind speed, the more the process of evaporation. In Fig. 3, we saw that the wind speed anomalies are maximum in August. Potential evaporation closely follows this pattern (Fig. 8(a)). A dip in potential evaporation during the third week of August is due to the lower 
atmospheric temperature resulting from cloud cover and precipitation. Precipitable water is the total amount of water vapour present in the entire column of the atmosphere of the unit area. Precipitation is closely related to column water vapour in the tropics (Muller et al. 2009; Neelin et al. 2009). On 15th August, we can see a peak in the precipitable water, which accounts for the extreme precipitation (Fig. 8(b)). According to Rangarajan and Mani (1982), the highest values of precipitable water over India observed during July- August occur between $50 \& 64 \mathrm{~kg} / \mathrm{m}^{2}$. Our observation agrees with their results.

\subsubsection{Latent Heat, Rainfall and Rainfall Anomaly}

Fig. 9

Fig. 9 shows the daily variations of latent heat flux, rainfall and rainfall anomaly averaged over the area, $75 \mathrm{E}-77 \mathrm{E} \& 5 \mathrm{~N}-12 \mathrm{~N}$. From 14-1 $7^{\text {th }}$ August, latent heat net flux values are highest in the month, coinciding with the maximum amount of precipitation. The latent heat released by convective activity is quickly distributed spatially by gravity waves. In the Kerala region, precipitation is at its peak on $14^{\text {th }}$ \& $15^{\text {th }}$ August (Fig. 9 (b)). From 7-1 $7^{\text {th }}$ August, continuously, there was above normal rainfall (Fig.9 (c)). Roca et al. (2014) suggested that around $75 \%$ of tropical rainfall occurs from mesoscale systems that last for more than 12 hours, whereas $60 \%$ of the rainfall is due to systems that travel more than $250 \mathrm{~km}$. The monsoon depression which formed in the head Bay on $14^{\text {th }}$ August 2018, persisted till $16^{\text {th }}$ August and travelled more than $600 \mathrm{~km}$ in the WNW direction before dissipation. This monsoon depression augmented the conditions for heavy precipitation over Kerala.

The heavy rainfall was associated with an offshore trough and a depression over the Bay of Bengal with a southward tilt of its axis with height and strong Low Level Jet (LLJ) (Viswanadhapalli et al. 2019). Their high-resolution modelling suggests high convective instability due to strong LLJ along with the offshore trough, transport of mid-tropospheric moisture under conducive vertical shear of horizontal wind and transport of moisture from the Bay of Bengal as the major factors behind extreme rainfall. According to Kumar et al. (2020), a propagating Low Pressure System (LPS) in the Bay of Bengal caused plenty of rainfall over the west coast of India, central India and the Bay of Bengal. The upper tropospheric anticyclone over the Middle East region inhibited the northward advancement of this LPS. On the other hand, on the west coast of India, a non-propagating offshore trough was observed. The synergic interaction between LPS, an intrusion of dry air into the mid-troposphere and the offshore trough are the main reasons for the extreme rainfall (Kumar et al. 2020). The performance of Numerical Weather Prediction (NWP) models used at the National Centre for Medium Range Weather Forecasting (NCMRWF) in the prediction of the extreme rainfall of Kerala during August 2018 was evaluated by Ashrit et al. (2020). They found that the deterministic NWP models were accurate at shorter lead times of up to three 
days and the ensemble-based probabilistic forecasts performed better at higher lead times beyond three days. Another study by Mohandas et al. (2020), suggested that a large amount of moisture from the tropical cyclones in the western North Pacific was transported to the upper troposphere over Kerala by a conveyor belt-like flow, which they termed as the 'Remotely Aligned Intense Tropical Circulations' (RAITC). Mukhopadhyay et al. (2021), while evaluating the performance of three global models, found a significant increase of moisture convergence over Kerala during the extreme precipitation event in August 2018 and that the extreme event was associated with a westward propagating barotropic Rossby wave.

All the Meteorological parameters that we investigated, namely, wind, vertical velocity, relative humidity, precipitable water, potential evaporation and zonal gravity wave stress, showed anomalously higher values in August 2018. Daily variations of OLR, wind speed anomaly, and precipitation indicated the active phase of an MJO during the second week of August 2018. Meridional mean values of vertical velocity between $5 \mathrm{~N} \& 15 \mathrm{~N}$ were maximum in the band of $70 \mathrm{E}-80 \mathrm{E}$ longitude. Another feature noticed during this period is the coincidence of the rising limbs of Hadley and Walker circulations over Kerala. The combined effect of all these factors enhanced the precipitation over Kerala and resulted in a devastating flood situation. Hence, it seems the anomalous weather conditions are more responsible for the extreme precipitation event of August 2018 over Kerala and the warming of the Arabian Sea might have influenced the development of the anomalous weather conditions.

\section{Summary And Conclusions}

Heavy precipitation is becoming more frequent and more intense in many parts of the world. The extreme precipitation and the consequent flooding of August 2018 in Kerala affected many lives and property. Different weather parameters during that period were investigated in this study. Most of the weather parameters showed anomalously high values during that time. Wind speeds greater than 16-18 $\mathrm{m} / \mathrm{s}$ occurred over Kerala, which was $6-8 \mathrm{~m} / \mathrm{s}$ above normal. This anomalous wind is mainly due to the monsoon depression that formed in the Head Bay during 14-16 August 2018. The anomalously high gravity wave stress intensified the zonal wind speed by which the Low Level Jet became stronger. Vertical velocity showed positive anomalies of $0.015 \mathrm{~m} / \mathrm{s}$. The atmosphere was $1-2 \mathrm{~K}$ cooler than the average due to higher vertical motion and the cooling by precipitation. In most parts of Kerala, the amount of precipitable water showed above-normal values of $50 \mathrm{~kg} / \mathrm{m}^{2}$. The presence of higher vertical motion and humidity helped condensation and the formation of clouds.

During the second week of August, OLR values are consistently low. However, the wind speed anomalies are consistently high for more than a week, confirming the active phase of a Madden Julian Oscillation during that period. Higher zonal gravity wave stress helped in the distribution of released latent heat and the occurrence of the high amount of water vapour content during these periods enhanced the MJO activity. This active phase enhanced the intensity and duration of the heavy precipitation. This 
anomalous precipitation can be observed from the above-normal values from $7^{\text {th }}$ to $17^{\text {th }}$ August. The high wind speed and shear near the surface improved the moisture transport to the atmosphere. Another important feature observed during the period is the Hadley and Walker circulations. The ascending limb of both the circulations was observed over Kerala, which helped the transportation of moisture to the upper levels. Potential evaporation is maximum in August, and the occurrence of the higher amount of precipitable water vapour coincides with the extreme precipitation events.

Almost all the weather parameters we studied create a favourable condition for the exceptionally heavy precipitation. This study indicates that the extreme precipitation event and the associated flooding over Kerala in August 2018 are more likely due to the anomalous weather conditions that persisted during that period. These include a positive phase of the Madden Julian Oscillation, which triggers an active monsoon phase, a strong LLJ, a near stationary monsoon depression over the Bay of Bengal, and a weak monsoon trough in the southeast Arabian Sea. The coincidence of the ascending limbs of Walker and Hadley circulations over Kerala, the occurrence of tropical easterly Jet with its core over Kerala/Karnataka and the wider extent of the mid-tropospheric cyclonic circulation with its western extent over Kerala was also favourable for heavy precipitation. A combination of all these factors resulted in a strong ascending motion of high humidity air resulting in extremely heavy rainfall over Kerala and resultant catastrophic floods.

\section{Acknowledgement}

Department of Science and Technology, Govt. of India, New Delhi is gratefully acknowledged for the financial assistance to Dr. S. S. Suneela through No. SR/WOS-A/EA-18/2018 dated 29-01-2019. Dr. E. N. Rajagopal, Head (Retd.), NCMRWF, Noida, is gratefully acknowledged for the critical comments and suggestions. The first author is thankful to Dr. Johnson Zacharia, CUSAT, Kochi and Dr. Suman Maity, JAMSTEC, Japan, for their help to learn the softwares GrADS and CDO.

\section{References}

Adames, Á F \& Maloney ED (2021) Moisture Mode Theory's Contribution to Advances in our Understanding of the Madden-Julian Oscillation and Other Tropical Disturbances. Curr Clim Chang Reports 1-14. https://doi.org/10.1007/s40641-021-00172-4

Agarwal R (2018) Original Research Article Lesson Learned from Killer Floods in Kerala: Time for Retrospection. Manag Econ Res J 4:268-280.

https://doi.org/https://doi.org/10.18639/MERJ.2018.04.735013

Ali H, Mishra V (2018) Increase in Subdaily Precipitation Extremes in India Under 1.5 and $2.0^{\circ} \mathrm{C}$ Warming Worlds. Geophys Res Lett 45:6972-6982. https://doi.org/10.1029/2018GL078689

Anandh PC, Vissa NK (2020) On the linkage between extreme rainfall and the madden-julian oscillation over the indian region. Meteorol Appl 27:1-16. https://doi.org/10.1002/met.1901 
Boyaj A, Ashok K, Ghosh S, et al (2018) The Chennai extreme rainfall event in 2015: The Bay of Bengal connection. Clim Dyn 50:2867-2879. https://doi.org/10.1007/s00382-017-3778-7

Boyaj A, Dasari HP, Hoteit I, Ashok K (2020) Increasing heavy rainfall events in south India due to changing land use and land cover. Q J R Meteorol Soc 146:3064-3085. https://doi.org/10.1002/qj.3826

CWC (2018) Kerala Floods of August 2018

Goswami BN, Venugopal V, Sangupta D, et al (2006) Increasing trend of extreme rain events over India in a warming environment. Science (80- ) 314:1442-1445. https://doi.org/10.1126/science.1132027

Guhathakurta P OPS and PAM (2011) Impact of climate change on extreme rainfall events and flood risk in India. J Earth Syst Sci 120, 120:359-373

Hunt KMR, Menon A (2020) The 2018 Kerala floods: a climate change perspective. Clim Dyn 54:24332446. https://doi.org/10.1007/s00382-020-05123-7

Joseph P V., Sijikumar S (2004) Intraseasonal variability of the low-level jet stream of the Asian summer monsoon. J Clim 17:1449-1458. https://doi.org/10.1175/1520-0442(2004)017<1449:IVOTLJ>2.0.C0;2

Kashyap A, Natu JC, Pise RS (2019) Cyclones and depressions over the north Indian ocean during 2018. Mausam 70:397-424. https://doi.org/http://metnet.imd.gov.in/mausamdocs/47031.pdf

Kharin V V., Zwiers FW, Zhang X, Hegerl GC (2007) Changes in temperature and precipitation extremes in the IPCC ensemble of global coupled model simulations. J Clim 20:1419-1444.

https://doi.org/10.1175/JCLI4066.1

Kumar S, Silva Y, Moya-Álvarez AS, Martínez-Castro D (2019) Seasonal and regional differences in extreme rainfall events and their contribution to the world's precipitation: GPM observations. Adv Meteorol 2019:6-9. https://doi.org/10.1155/2019/4631609

Kumar SP, Roshin RP, Narvekar J, et al (2009) Response of the Arabian Sea to global warming and associated regional climate shift. Mar Environ Res 68:217-222.

https://doi.org/10.1016/j.marenvres.2009.06.010

Kumar V, Pradhan PK, Rao SVB, Sinha T (2020) atmosphere Interaction of a Low-Pressure System , an Off shore Trough, and Mid-Tropospheric Dry Air Intrusion: The Kerala Flood of August 2018. Atmosphere (Basel) 11:740. https://doi.org/10.3390/atmos11070740

Min SK, Zhang X, Zwiers FW, Hegerl GC (2011) Human contribution to more-intense precipitation extremes. Nature 470:378-381. https://doi.org/10.1038/nature09763

Mishra AK (2019) Quantifying the impact of global warming on precipitation patterns in India. Meteorol Appl 26:153-160. https://doi.org/10.1002/met.1749 
Mishra V, Aaadhar S, Shah H, et al (2018) The Kerala flood of 2018: combined impact of extreme rainfall and reservoir storage. Hydrol Earth Syst Sci Discuss 1-13. https://doi.org/10.5194/hess-2018-480

Mishra V, Shah HL (2018) Hydroclimatological Perspective of the Kerala Flood of 2018. J Geol Soc India 92:645-650. https://doi.org/10.1007/s12594-018-1079-3

Mohandas S, Francis T, Singh V, et al (2020) NWP perspective of the extreme precipitation and flood event in Kerala (India) during August 2018. Dyn Atmos Ocean 91:101158.

https://doi.org/10.1016/j.dynatmoce.2020.101158

Mukherjee S, Aadhar S, Stone D, Mishra V (2018) Increase in extreme precipitation events under anthropogenic warming in India. Weather Clim Extrem 20:45-53.

https://doi.org/10.1016/j.wace.2018.03.005

Mukhopadhyay P, Bechtold P, Zhu Y, Murali RP (2021) Unravelling the mechanism of extreme ( more than 30 sigma ) precipitation during August 2018 and 2019 over Kerala , India. Weather Forecast 5:20182019. https://doi.org/https://doi.org/10.1175/WAF-D-20-0162.1

Muller CJ, Back LE, O'Gorman PA, Emanuel KA (2009) A model for the relationship between tropical precipitation and column water vapor. Geophys Res Lett 36:1-5. https://doi.org/10.1029/2009GL039667

Myhre G, Alterskjær K, Stjern CW, et al (2019) Frequency of extreme precipitation increases extensively with event rareness under global warming. Sci Rep 9:1-10. https://doi.org/10.1038/s41598-019-52277-4

Neelin JD, Peters O, Hales K (2009) The transition to strong convection. J Atmos Sci 66:2367-2384. https://doi.org/10.1175/2009JAS2962.1

Nikumbh AC, Chakraborty A, Bhat GS, Frierson DMW (2020) Large-Scale Extreme Rainfall-Producing Synoptic Systems of the Indian Summer Monsoon. Geophys Res Lett 47:1-15.

https://doi.org/10.1029/2020GL088403

O'Gorman PA (2015) Precipitation Extremes Under Climate Change. Curr Clim Chang Reports 1:49-59. https://doi.org/10.1007/s40641-015-0009-3

Pai DS, Sridhar L, Badwaik MR, Rajeevan M (2015) Analysis of the daily rainfall events over India using a new long period $(1901-2010)$ high resolution $\left(0.25^{\circ} \times 0.25^{\circ}\right)$ gridded rainfall data set. Clim Dyn $45: 755-$ 776. https://doi.org/10.1007/s00382-014-2307-1

Pall P, Allen MR, Stone DA (2007) Testing the Clausius-Clapeyron constraint on changes in extreme precipitation under CO2 warming. Clim Dyn 28:351-363. https://doi.org/10.1007/s00382-006-0180-2

Peng J, Dadson S, Leng G, et al (2019) The impact of the Madden-Julian Oscillation on hydrological extremes. J Hydrol 571:142-149. https://doi.org/10.1016/j.jhydrol.2019.01.055 
Ramaswamy C (1985) Review of floods in India during the past 75 years. Indian Natl Sci Acad 5-11

Rangarajan S, Mani A (1982) Total precipitable water in the atmosphere over India. Proc Indian Acad Sci Earth Planet Sci 91:189-207. https://doi.org/10.1007/BF02841678

Roca R, Aublanc J, Chambon P, et al (2014) Robust observational quantification of the contribution of mesoscale convective systems to rainfall in the tropics. J Clim 27:4952-4958.

https://doi.org/10.1175/JCLI-D-13-00628.1

Roxy MK, Dasgupta P, McPhaden MJ, et al (2019) Twofold expansion of the Indo-Pacific warm pool warps the MJO life cycle. Nature 575:647-651. https://doi.org/10.1038/s41586-019-1764-4

Roxy MK, Ghosh S, Pathak A, et al (2017) A threefold rise in widespread extreme rain events over central India. Nat Commun 8:1-11. https://doi.org/10.1038/s41467-017-00744-9

Santer BD, Mears C, Wentz FJ, et al (2007) Identification of human-induced changes in atmospheric moisture content. Proc Natl Acad Sci U S A 104:15248-15253.

https://doi.org/10.1073/pnas.0702872104

Sudheer KP, Murty Bhallamudi S, Narasimhan B, et al (2019) Role of dams on the floods of August 2018 in Periyar River Basin, Kerala. Curr Sci 116:780-794. https://doi.org/10.18520/cs/v116/i5/780-794

Trenberth KE, Dai A, Rasmussen RM, Parsons DB (2003) The changing character of precipitation. Bull Am Meteorol Soc 84:1205-1217+1161. https://doi.org/10.1175/BAMS-84-9-1205

Varikoden H, Revadekar J V. (2020) On the extreme rainfall events during the southwest monsoon season in northeast regions of the Indian subcontinent. Meteorol Appl 27:1-13.

https://doi.org/10.1002/met.1822

Viswanadhapalli Y, Srinivas CV, Basha G, et al (2019) A diagnostic study of extreme precipitation over Kerala during August 2018. Atmos Sci Lett 20:1-10. https://doi.org/10.1002/asl.941

Willett KM, Gillett NP, Jones PD, Thorne PW (2007) Attribution of observed surface humidity changes to human influence. Nature 449:710-712. https://doi.org/10.1038/nature06207

\section{Declarations}

\section{Funding}

This work was done with the financial support of the Department of Science and Technology, Govt. of India, New Delhi to Dr. S. S. Suneela through No. SR/WOS-A/EA-18/2018 dated 29-01-2019.

\section{Conflicts of interest/Competing interests}


The authors declare that we have no known competing financial interests or personal relationships that could have appeared to influence the work reported in this paper.

\section{Availability of data and material}

The data used for this study are readily available from the sites

https://psl.noaa.gov/

https://www.ecmwf.int > datasets > reanalysis-datasets

https://coastwatch.noaa.gov/

https://www.imdpune.gov.in/Clim_Pred_LRF_New/Grided_Data_Download.html

Code availability (software application or custom code)

GrADS, CDO, Adobe illustrator and Inkscape

\section{Authors' contributions}

- Suneela S S:- conceptualization, data curation, investigation, writing \& funding acqisition

- Basil Mathew:- conceptualization, investigation \& writing

- Suresh Kumar:- Supervision, review

\section{ORCID IDs of authors}

S S Suneela

S Sureshkumar

Basil Mathew

\section{Figures}

0000-0003-2565-1056

0000-0001-5609-4024

000-0002-0151-2783 
Wind
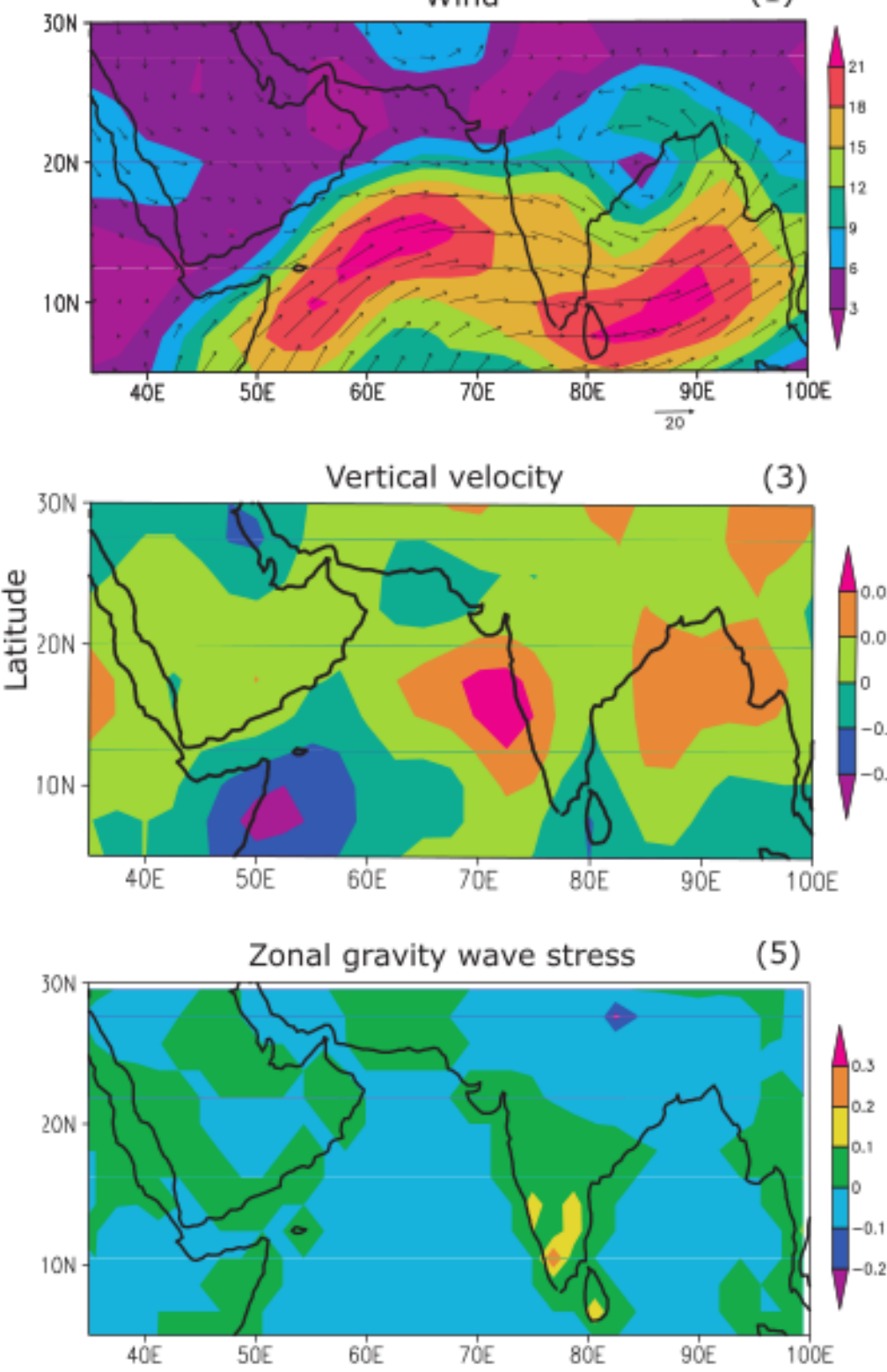
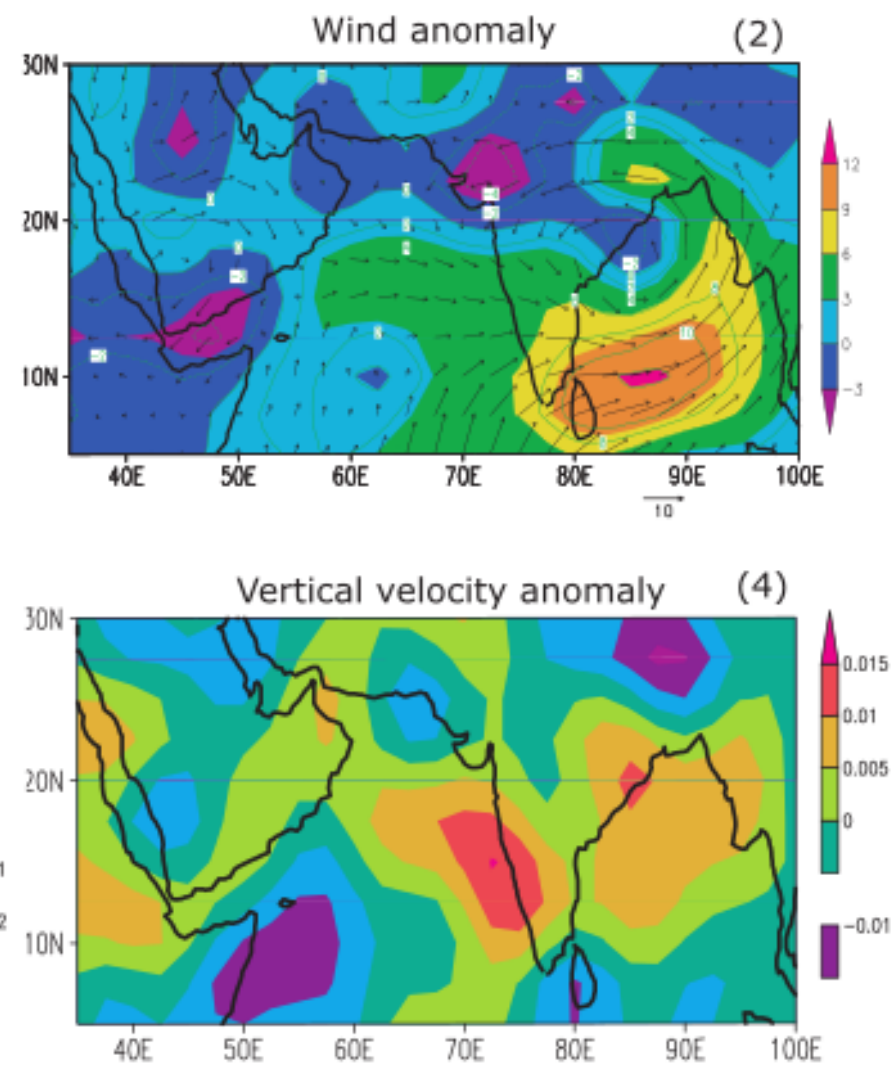

(6)

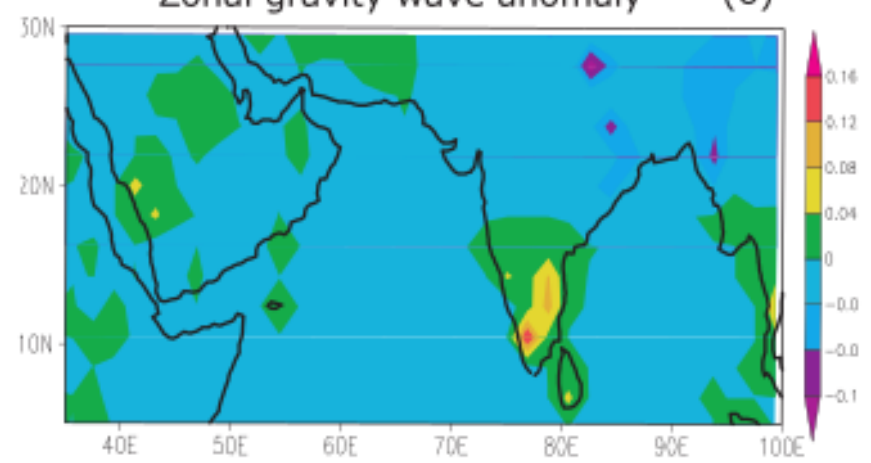

Longitude

Figure 1

Spatial distribution of wind $(\mathrm{m} / \mathrm{s})$, vertical velocity $(\mathrm{m} / \mathrm{s})$ and zonal gravity wave stress $(\mathrm{N} / \mathrm{m} 2)$ and their anomalies on 15th August 2018 at $850 \mathrm{hPa}$ 
(a) Precipitable water

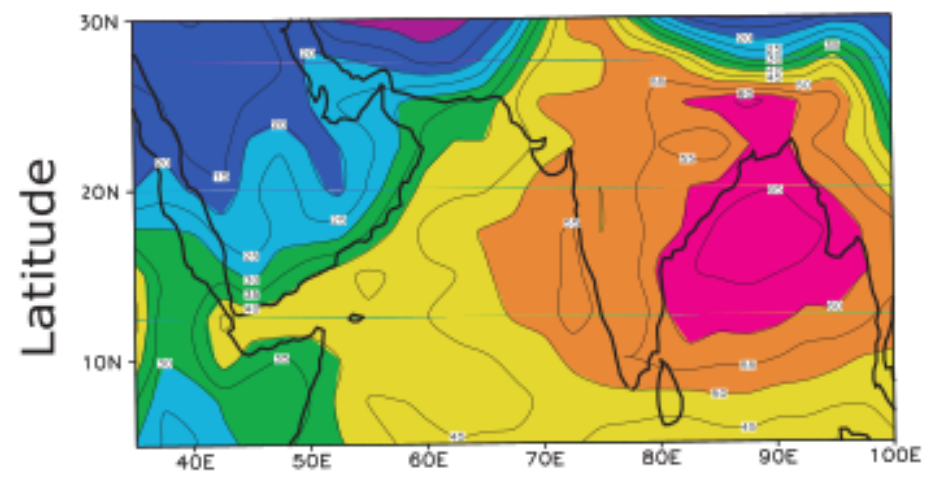

(b) Precipitable water anomaly

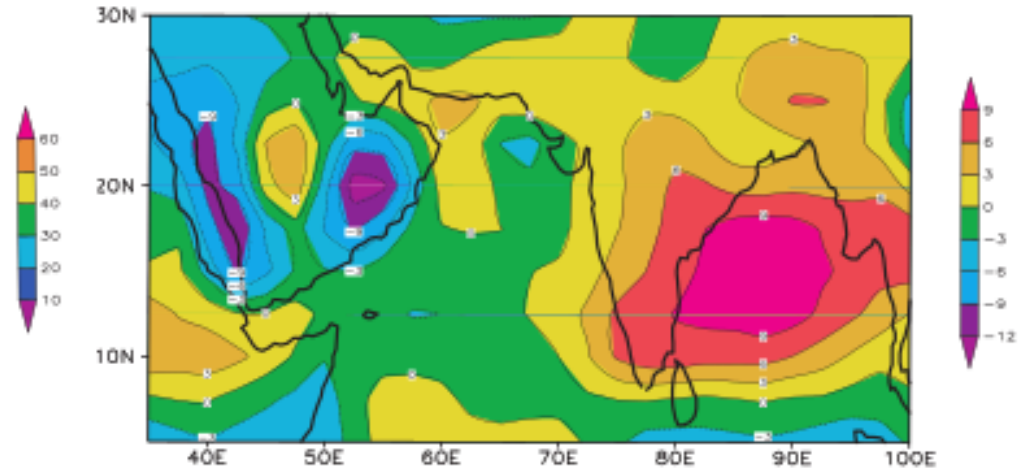

\section{Longitude}

\section{Figure 2}

Spatial distribution of (a) precipitable water $(\mathrm{kg} / \mathrm{m} 2)$ and (b) its anomaly on 15th August 2018.

(a) OLR

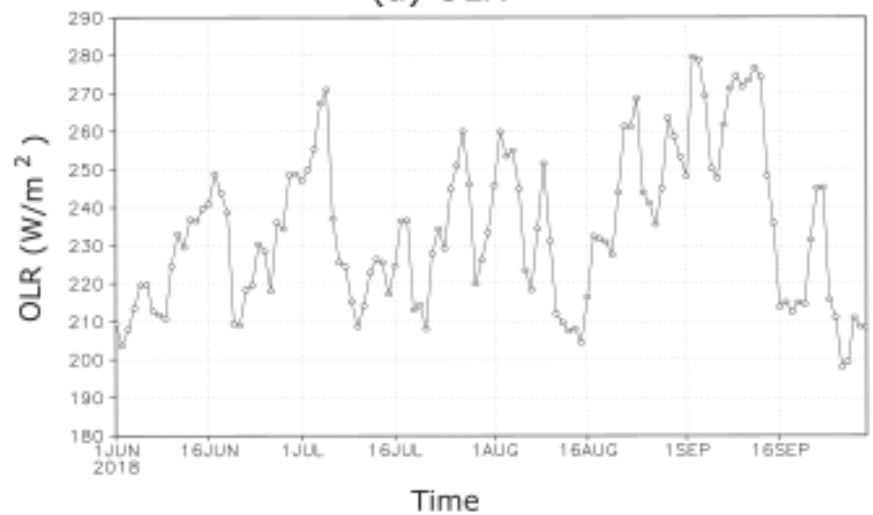

(b) Wind speed anomaly

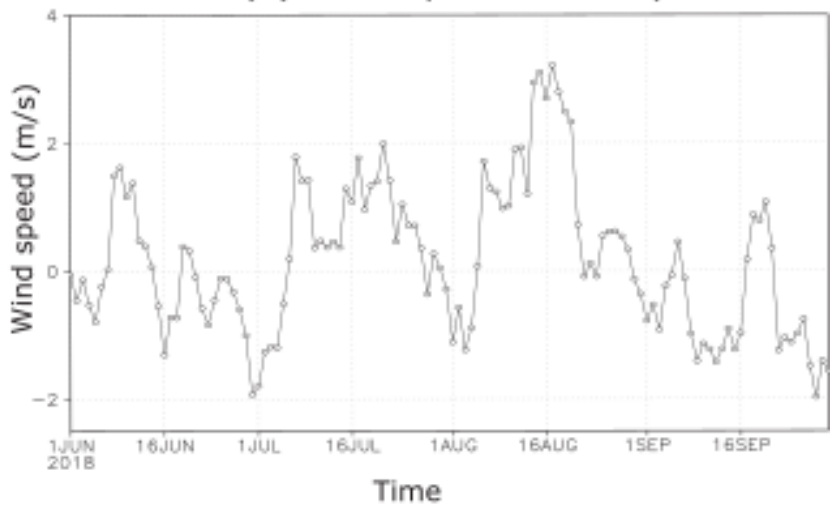

Figure 3

Hovmoller diagram of (a) OLR (W/m2) and (b) wind speed (m/s) anomaly

(a) Meridional mean vertical velocity

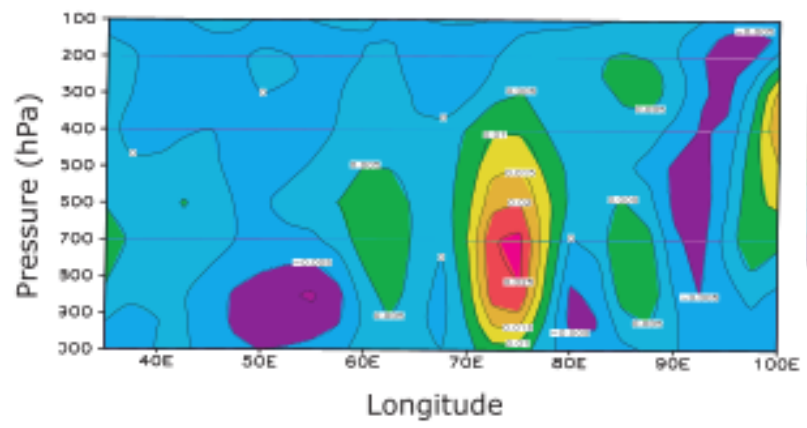

(b) Meridional mean vertical velocity anomaly

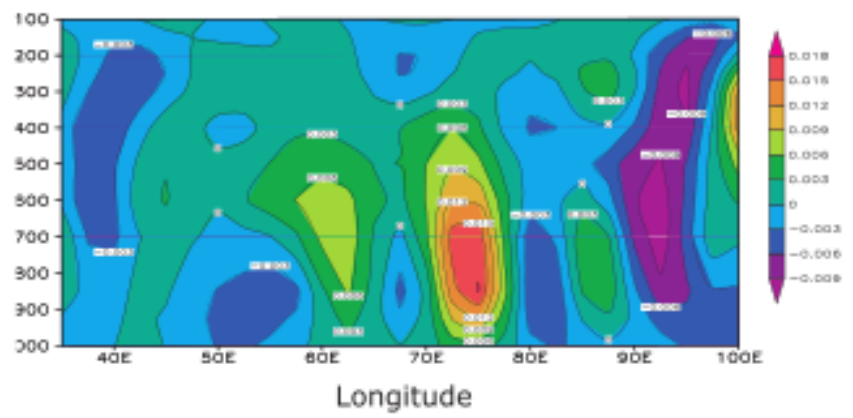

\section{Figure 4}


Meridional means of (a) vertical velocity $(\mathrm{m} / \mathrm{s})$ and $(\mathrm{b})$ its anomalies between $5 \mathrm{~N} \& 15 \mathrm{~N}$ on 15th August 2018

(a) Hadley Circulation

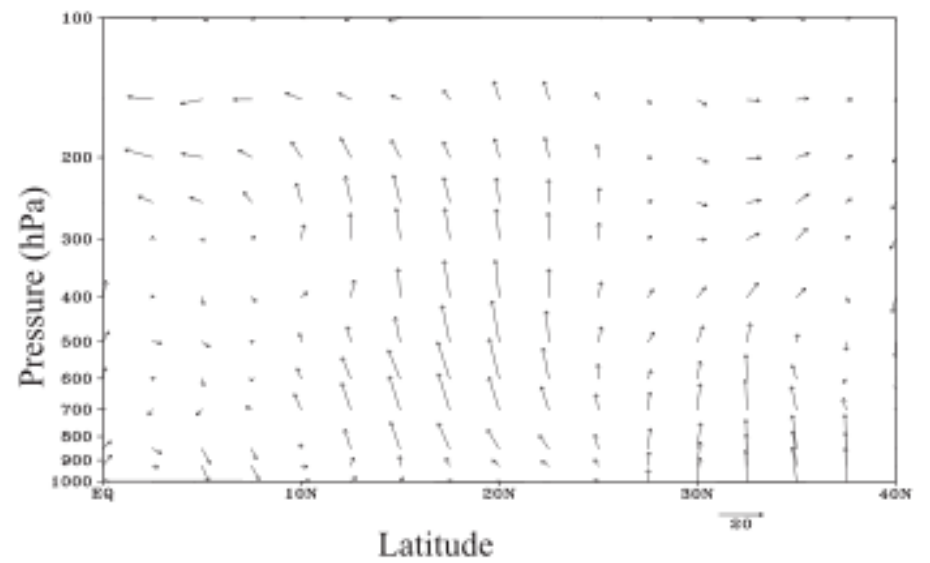

(b) Walker Circulation

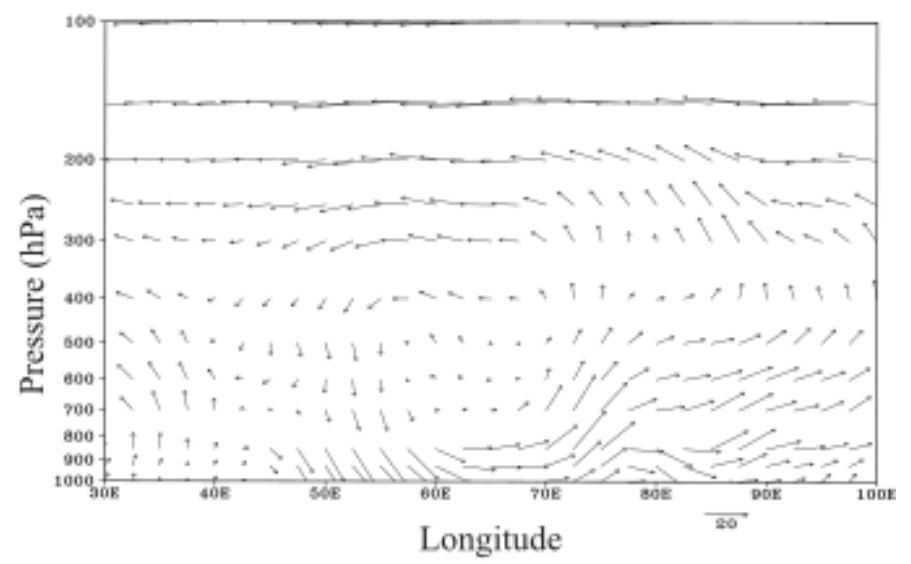

\section{Figure 5}

Hadley and Walker Circulations on 15th August 2018

(a) Wind at $500 \mathrm{hPa}$

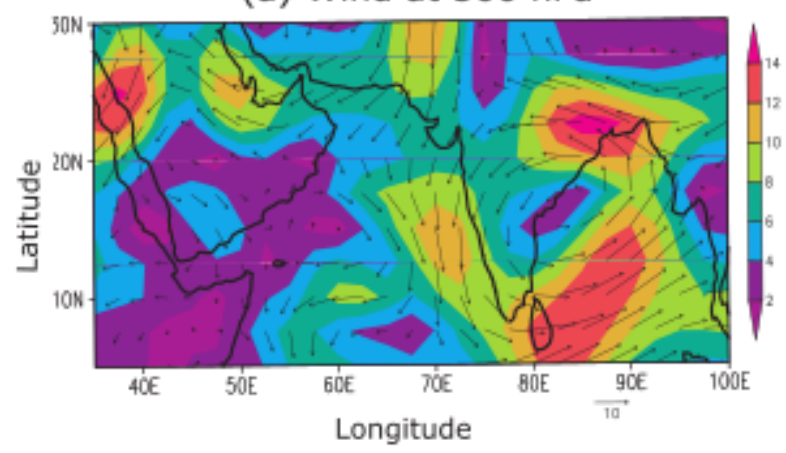

(b) Wind at $100 \mathrm{hPa}$

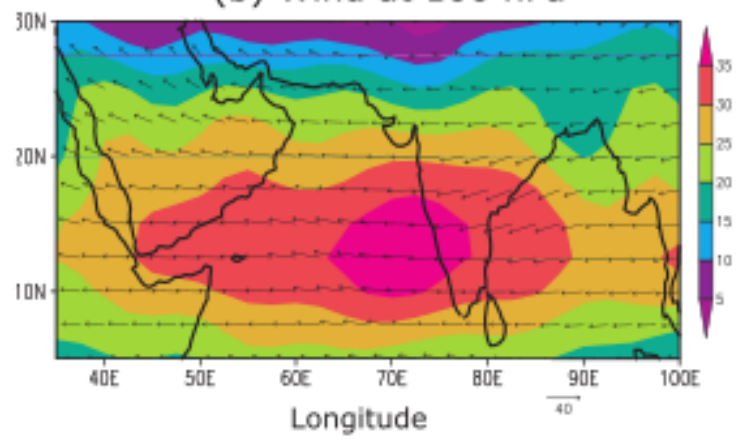

Figure 6

Spatial variation of wind vector and wind speed (m/s) (shaded) at (a) $500 \mathrm{hPa}$ and (b) $100 \mathrm{hPa}$ on 15th August 2018 
(a) Precipitation

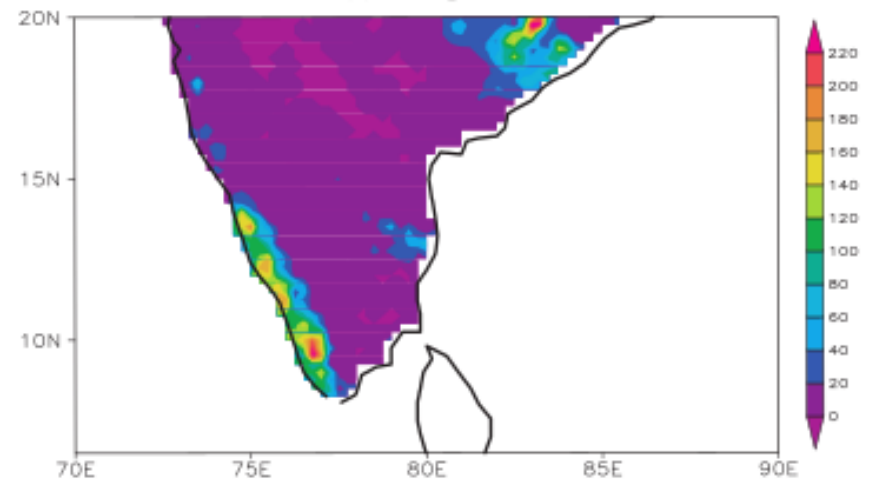

(b) Lapse rate

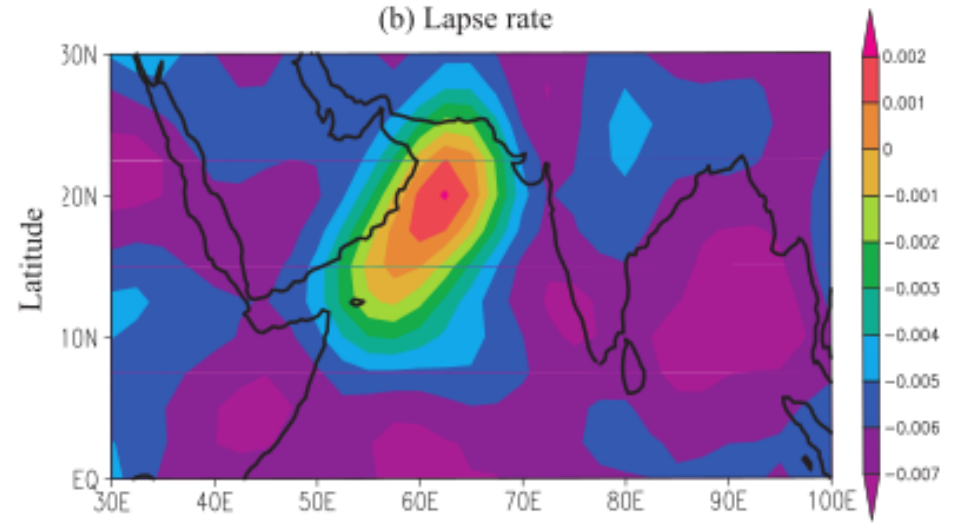

(c) Divergence \& vorticity

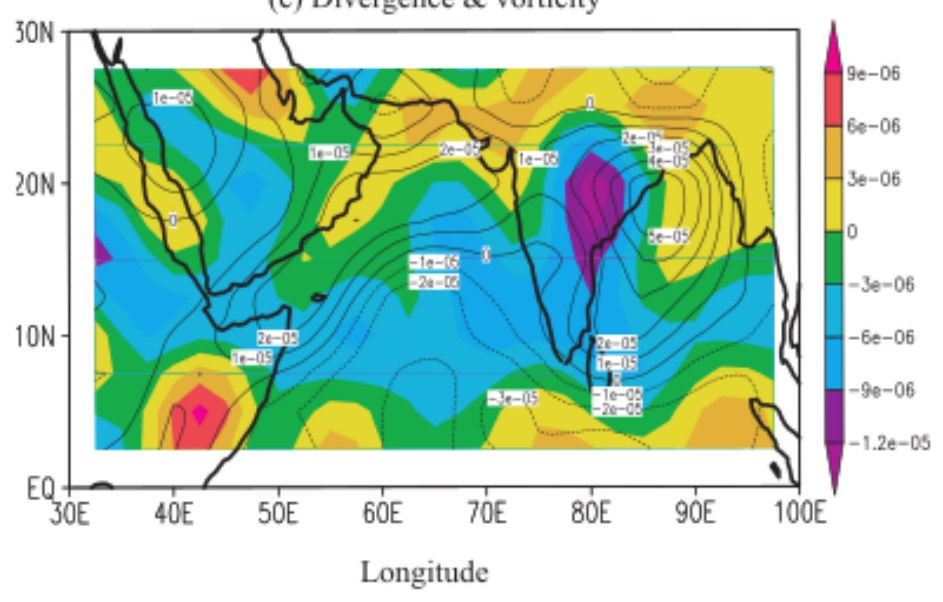

\section{Figure 7}

(a) Spatial variation of rainfall $(\mathrm{mm})$ from IMD data, (b) lapse rate $(0 \mathrm{C} / \mathrm{km})$ at $925 \mathrm{hPa}$ and (c) divergence (s-1) (shaded) and vorticity (s-1) (contours) at $850 \mathrm{hPa}$ on 15th August 2018 
(a) Potential evaporation rate

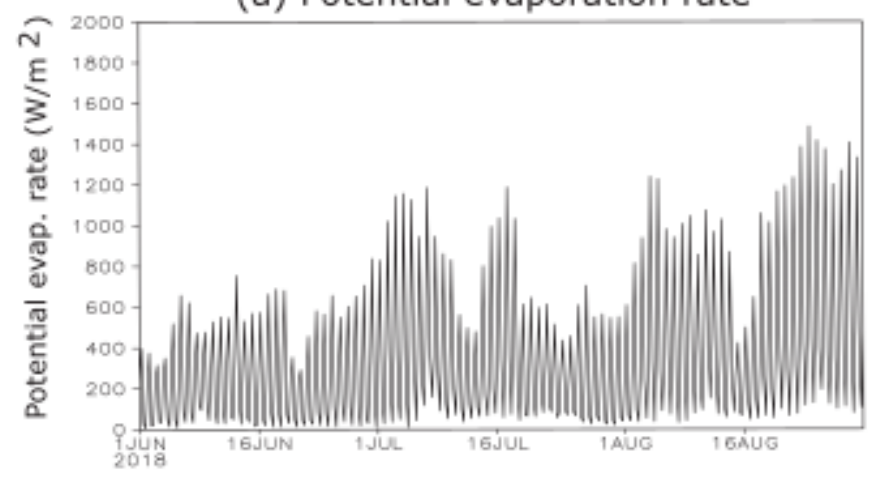

(b) Precipitable water

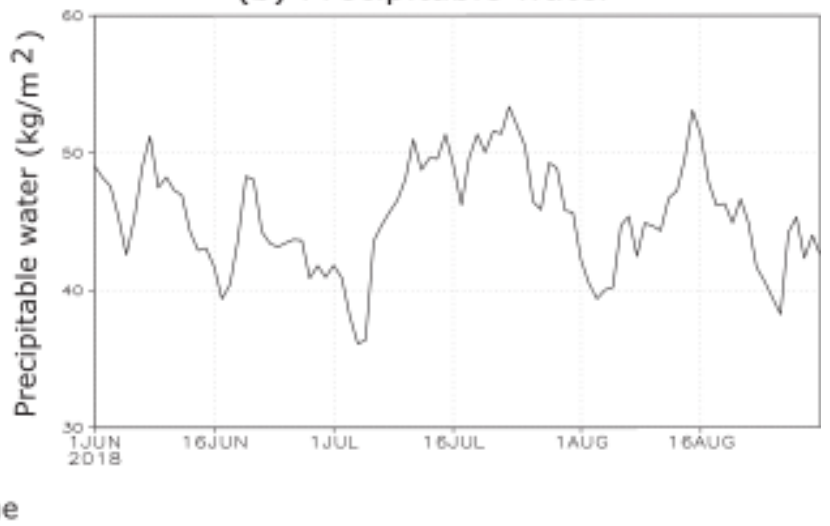

Figure 8

(a) Potential evaporation rate $(\mathrm{W} / \mathrm{m} 2)$ and (b) precipitable water $(\mathrm{kg} / \mathrm{m} 2)$, area average between $75 \mathrm{E}-77 \mathrm{E}$ \& 8 N-12 N during June-August 2018 
(a) Latent heat

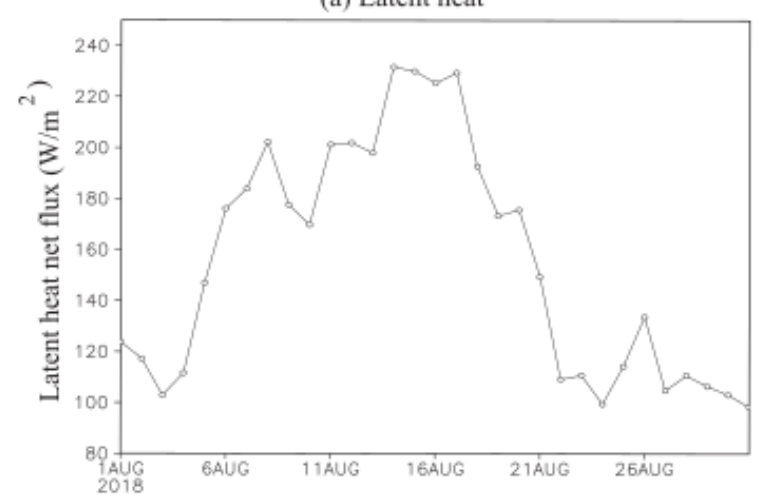

(b) Precipitation

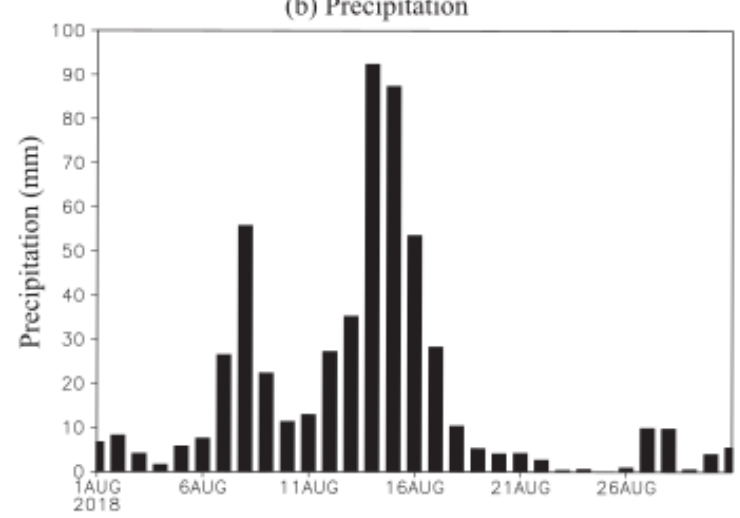

(c) Precipitation Anomaly

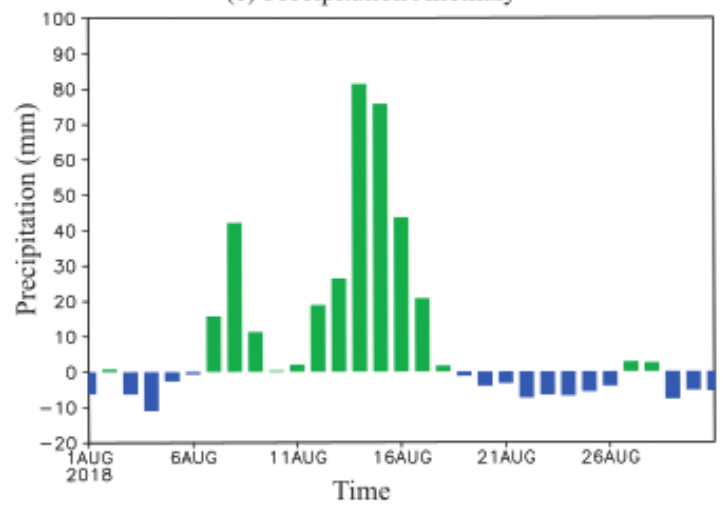

Figure 9

(a) Latent heat net flux (W/m2), (b) precipitation $(\mathrm{mm})$ and (c) precipitation anomaly $(\mathrm{mm})$ between $75 \mathrm{E}$ $77 \mathrm{E}$ and $5 \mathrm{~N}-12 \mathrm{~N}$ in August 2018 